\title{
Validity of bone scans to detect missed injury in patients with major trauma
}

\author{
Maru Kim, M.D., (ㄱ) Tae Hwa Hong, M.D., 닥 Hang Joo Cho, M.D.
}

Department of Trauma Surgery, Uijeongbu St. Mary's Hospital, The Catholic University of Korea, Cheonbo-ro Uijeongbu-si - South Korea

\begin{abstract}
BACKGROUND: It is easy to miss injuries in patients with major trauma (MT). The authors hypothesized that bone scans (BSs) would reduce the number of missed injuries. However, there was not enough evidence on BS in patients with MT. The purpose of the present study was to identify the basic results of BS in patients with MT.

METHODS: The medical records of patients with MT between January 2013 and December 2013 were reviewed. Patients who underwent a BS were enrolled in the study. Hot-uptake lesions without previous evaluation were checked by X-ray. Hot-uptake lesions on BSs that differed from previous evaluations were checked by computed tomography (CT) scans. The results of BSs were analyzed along with the results of X-ray and CT scans. The sensitivity, specificity, positive predictive value, and negative predictive value (NPV) were calculated.
\end{abstract}

RESULTS: There were 115 patients with MT who received BS during the study period. The sensitivities were high on average (98.48-86.54). In addition, the NPVs were high (96.30-82.93). There were 16 cases of hidden fracture diagnosed after a BS.

CONCLUSION: BS showed high sensitivity and high NPV. Further large-scale studies might add more validity to the use of BS in patients with MT.

Keywords: Bone scan; missed injury; tertiary survey; trauma.

\section{INTRODUCTION}

When managing patients with major trauma (MT), physicians often encounter several unexpected events, and missed injury is one of them. The incidence of missed injury might be as high as $38 \% .^{\left[{ }^{I]}\right.}$ Airway maintenance, intubation, damage control surgery (DCS), and ventilator care are usually done prior to checking the extremities in initial management. It has been reported that patients with multiple traumas, traumatic brain injury, and decreased mental functioning were likely to have missed injuries. ${ }^{[2,3]}$ This may be associated with poorer outcomes, such as increased morbidity and mortality, and requires proper evaluation. ${ }^{[4,5]}$

The brain, chest, and abdomen were routinely checked by computed tomography (CT) for stable patients with the possibility of MT. Subsequent to initial resuscitation, the entire abnormal region was checked by $\mathrm{X}$-ray according to the review of the system and physical examination. Painful regions without definite fracture or external wounds were regarded as contusion, sprain, or strain that could be managed conservatively. However, there were some patients with a complaint of continuous pain. In such cases, physicians can prescribe $\mathrm{CT}$, magnetic resonance imaging (MRI), or bone scan (BS). Among these examinations, BS is the cheapest examination under the Korean National Health Insurance System (Table I). It detects technetium-99 m-labeled bisphosphonates. ${ }^{[6]}$ It binds to sites of increased osteoblastic activity, such as physiological growth or turn-over. Thus, it is commonly used for the detection and follow-up of malignant lesions; however, it could also reveal injury or mechanical stress and can detect sites of fracture. In addition, it could

Cite this article as: Kim M, Hong TH, Cho HJ. Validity of bone scans to detect missed injury in patients with major trauma. Ulus Travma Acil Cerrahi Derg 2019;25:183-187.

Address for correspondence: Hang Joo Cho, M.D.

27I, Cheonbo-ro Uijeongbu-si - South Korea.

Tel: 82-3I-820-5378 E-mail: 10602800@cmcnu.or.kr

Ulus Travma Acil Cerrahi Derg 2019;25(2):183-187 DOI: 10.5505/tjtes.2018.55068 Submitted: 16.08.2017 Accepted: 26.07.2018 Online: 15.03.2019

Copyright 2019 Turkish Association of Trauma and Emergency Surgery 
evaluate the whole body in one study. Therefore, the authors selected BS as screening tool to detect missed injury in patients with trauma initially.

However, evidence regarding the application of BS in cases of MT is insufficient. The present study analyzed the accuracy of BS in MT as a screening tool to detect missed injury.

\section{MATERIALS AND METHODS}

This was a retrospective study of patients with MT, defined as patients with an Injury Severity Score (ISS) of $\geq 16$. The medical records of patients with trauma treated between January 2013 and December 2013 were reviewed. Patients who underwent a BS were included in the study. However, patients with other diseases, such as cancer or a history of osteomyelitis, were excluded from the study. This is because bone metastasis or osteomyelitis also results in hot uptake on a BS. Patients' general information, such as sex, age, height, and weight, was collected. In addition, ISS and time between trauma and BS were recorded.

The basic treatment policy was as follows. The brain, chest, abdomen, and spine were routinely checked via $\mathrm{CT}$ in the emergency room. Every site that patients complained had pain or discomfort was checked by a simple X-ray after stabilization. BS was generally planned 7 days after trauma. Hotuptake lesions without previous evaluation were checked by

Table I. Cost of CT, MRI, and bone scan in the Korean National Health Insurance System

\begin{tabular}{lc}
\hline Examination & Cost (US) \\
\hline Bone scan & 148.37 \\
Knee computed tomography & 206.39 \\
Spine computed tomography & 234.86 \\
Knee magnetic resonance imaging & 248.11 \\
Spine magnetic resonance imaging & 348.78 \\
\hline CT: Computed tomography, MRI: Magnetic resonance imaging. &
\end{tabular}

X-ray. Hot-uptake lesions in BS that differed from the results of a previous evaluation were checked by CT.

Any identified fracture seen on X-ray or CT was defined as a real fracture, and hot-uptake lesions seen on the BS were defined as positive findings. BS results were compared with $\mathrm{X}$-ray or $\mathrm{CT}$. Lesions with positive findings on $\mathrm{BS}$ and real fractures seen on X-ray or CT were regarded as true fractures. Lesions with positive findings on BS and without real fractures on X-ray or CT were regarded as false fractures. In addition, there were some real fractures that were not diagnosed at the initial evaluation and could be diagnosed through further evaluation after BS. These lesions were regarded as hidden fractures.

For analysis, the skeletal system was divided into four subgroups: chest, lower extremities (LEs), upper extremities (UEs), and spine. The ribs, sternum, and scapula were regarded as the chest. The pelvis to the toes was considered as the LE. The clavicle to the fingers was grouped into the UE. The skull and the face were also analyzed as the UE. The BS results were analyzed along with the results of $X$-ray and $C T$ scans. The sensitivity, specificity, positive predictive value, and negative predictive value (NPV) were calculated. Our hospital's Institutional Review Board approved the study. Informed consent was waived since this was a retrospective study.

\section{RESULTS}

A total of 304 patients with MT were found during the study period. BS was performed on I I 5 patients, and these patients were enrolled in the study. There were 76 (66.1\%) male and $39(33.9 \%)$ female patients. The mean age of the patients was 47.9 years. The mean ISS was 23.8 , and the mean time from trauma to BS was II.7 days.

Table 2 and Fig. I show the results of BS for detecting fracture. Sensitivity, an important point for a screening test, was high on average (>90\%). The chest showed the highest sensitivity with $98.48 \%$, followed by the LE with $97.44 \%$. In addition, NPV was high on average. The NPV of the LE was $97.14 \%$, and that of the chest was $96.30 \%$. However, specificity was

Table 2. Results of bone scans used to detect fractures in patients with major trauma

\begin{tabular}{|c|c|c|c|c|c|c|c|c|}
\hline \multirow[b]{2}{*}{ Bone scan } & \multicolumn{2}{|c|}{ Chest } & \multicolumn{2}{|c|}{ Upper extremity } & \multicolumn{2}{|c|}{ Lower extremity } & \multicolumn{2}{|c|}{ Spine } \\
\hline & $(+)$ & $(-)$ & $(+)$ & $(-)$ & $(+)$ & $(-)$ & $(+)$ & $(-)$ \\
\hline Fracture $(+)$ & 65 & 1 & 45 & 7 & 38 & 1 & 39 & 3 \\
\hline Fracture (-) & 21 & 26 & 24 & 34 & 30 & 34 & 12 & 58 \\
\hline Sensitivity & \multicolumn{2}{|c|}{98.48} & \multicolumn{2}{|c|}{86.54} & \multicolumn{2}{|c|}{97.44} & \multicolumn{2}{|c|}{92.86} \\
\hline Specificity & \multicolumn{2}{|c|}{55.32} & \multicolumn{2}{|c|}{58.62} & \multicolumn{2}{|c|}{53.13} & \multicolumn{2}{|c|}{82.86} \\
\hline Positive predictive value & \multicolumn{2}{|c|}{75.58} & \multicolumn{2}{|c|}{65.22} & \multicolumn{2}{|c|}{55.88} & \multicolumn{2}{|c|}{76.47} \\
\hline Negative predictive value & \multicolumn{2}{|c|}{96.30} & \multicolumn{2}{|c|}{82.93} & \multicolumn{2}{|c|}{97.14} & \multicolumn{2}{|c|}{95.08} \\
\hline
\end{tabular}


Table 3. Cases of hidden fracture

\begin{tabular}{lcc}
\hline Lesion & $\mathbf{n}$ & $\%$ \\
\hline Tibia & 6 & 38 \\
Fibula & 4 & 25 \\
Patella & 3 & 19 \\
Miscellaneous & 3 & 19 \\
Total & 16 & 100 \\
\hline
\end{tabular}

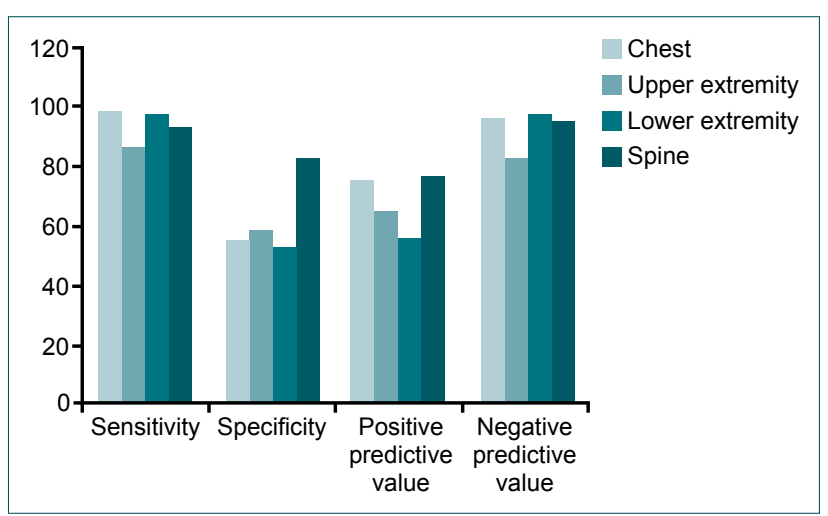

Figure 1. Sensitivity, specificity, positive predictive value, and negative predictive value of bone scan in patients with major trauma.

relatively low. Specificity in the LE was only $53.13 \%$, and that in the chest was $55.32 \%$.

There were 16 cases of hidden fracture diagnosed after BS (Table 3). Almost all the hidden fractures were found in the LE. Tibia fracture was the most common hidden fracture $(n=6,38.8 \%)$, followed by fibula fracture $(n=4,25.0 \%)$.

\section{DISCUSSION}

Recently, by applying DCS and other advanced critical care methods, trauma surgery has advanced, and mortality has decreased. ${ }^{[7]}$ Patients requiring DCS are in emergency situations, and physicians usually focus on injuries to the brain, chest, and abdomen during initial resuscitation; therefore, it is easy to overlook skeletal injuries. It has been reported that $12 \%$ of patients with MT had missed injuries after the initial evaluation. ${ }^{[8]}$ However, further guidelines or specialized studies for evaluation after critical care are lacking. ${ }^{\left[{ }^{9]}\right.}$ In the present study, the authors analyzed the results of BS in MT as a tool to diagnose missed skeletal injuries.

It is reported that BS is the best diagnostic study to diagnose clinically suspected fracture. ${ }^{[10]}$ By applying BS to $M T$, the authors identified 16 (5.3\%) patients with hidden fractures that were missed in the fracture diagnosis process using simple $X$-rays. The authors believed that it could prevent further medical and legal problems. Delayed diagnosis and treatment of fracture have been reported to be associated with poorer outcomes including not only malunion and nonunion but also pulmonary complications and length of stay. ${ }^{[1-14]}$ By applying BS, physicians could properly detect the hidden fracture and reduce the related morbidities. Additionally, reducing hidden fracture is important at the time of legal action. The common etiology of MT in Korea is a blunt injury caused by traffic and industrial accidents that require suing for the damage caused. The missed injury could be disadvantageous for patients during the legal process. Especially, patients with traumatic brain injury, those under ventilator care, or those who could not complain about their symptoms could gain benefits from BS.

As a screening tool for detecting fractures in patients with MT, BS has some merits. First, BS displayed high sensitivity in the present study (mean, 94\% [86.5\%-98.5\%]). High sensitivity is one of the main factors necessary for a screening tool. The sensitivity of a fecal occult blood test for colorectal cancer was reported to range from $73 \%$ to $92 \%$, and that of mammography for breast cancer in high-risk women was reported to be $37.5 \%$ to $55.6 \% .^{[15,16]}$ Compared with these well-known screening methods, BS could yield strong results. Additionally, BS showed a high NPV. Therefore, negative results on a BS can be used as evidence to halt further unnecessary, repetitious evaluations. Thus, the use of BS may prevent increasing medical costs, prevent wasting patients' time, and decrease patients' radiation exposure.

The dose of radiation received during a BS is also low. The radiation dose received during a BS using Tc $99 \mathrm{~m}$ bisphosphonate was reported to be $6.0 \mathrm{mSv} .^{[6]}$ This is higher than the radiation dose associated with a chest $X$-ray $(0.1 \mathrm{mSv})$ but is lower than those received during a pulmonary angiogram CT or abdominal and pelvic CT (I3.7-15.0 mSv). One study examined the use of whole-body CT scan in patients with MT. ${ }^{[17]} \mathrm{A}$ malignancy risk is present after radiation exposure. $\left[{ }^{[18,19]}\right.$ Considering that being less invasive is one of the main requirements of a screening tool, BS has an advantage as a screening method. MRI is an alternative method with no radiation exposure. However, it is the most expensive examination tool and requires a long time for single examination. Therefore, it has limitations as a screening tool.

On the other hand, the limitation of BS is its relatively low specificity. This is because BS detects not only fractures but also every site with increased osteoblastic activity. Although patients with malignancies were excluded because of the possibility of bone metastasis, there exist other causes of hot uptake in BS, such as bony contusions or chronic osteoarthritis, and such patients require further imaging studies for proper diagnosis. Therefore, BS cannot diagnose fracture alone, and other evaluations, such as X-ray or CT scans, are required. However, to reduce the incidence of missed injury and morbidity and mortality associated with delayed treatment, repetitive check-ups may be preferable in this situation. In addition, further study to develop the diagnostic modality that can distinguish acute fracture from old fracture, inflammation, or tumor is required. Additionally, further study to 
check missed injury in pregnant patients or other patients who are vulnerable to radiation is required.

In addition, the medical cost might be a problem. With BS, the authors could identify 16 (5.3\%) patients with hidden fractures that might have been missed in the fracture diagnosis process. However, in the case of patients with unidentified missed injury, BS might be an unnecessary examination that increases medical cost. In a reported study, the cost-effectiveness for CT and MRI has been evaluated; however, analysis about BS was lacking. ${ }^{[20]}$ The cost-effectiveness of BS for fracture screening in patients with $M T$ is required.

Furthermore, the present study analyzed the sensitivity, specificity, and other statistical parameters of patients with MT and did not compare patients who did not undergo BS. To fully examine the validity of BS as a screening tool for missed injury in MT, further randomized controlled trials are essential. Other analyses of the results of BS and initial conditions following intubation, such as mental status, DCS, or further management or prognosis after BS, are currently lacking. However, even basic statistical results on BS were initially insufficient. The present study can serve as a pilot study that grants evidence in favor of further studies on BS in MT.

In conclusion, BS was associated with high sensitivity and other positive statistical parameters and has promise as a screening tool to detect missed injury in patients with MT. Furthermore, it has a high NPV, which is useful to confirm that no further evaluation for missed fractures is necessary. Further systemized studies will provide higher validity and feasibility to BS.

Conflict of interest: None declared.

\section{REFERENCES}

1. Thomson CB, Greaves I. Missed injury and the tertiary trauma survey. Injury 2008;39:107-14. [CrossRef]

2. Giannakopoulos GF, Saltzherr TP, Beenen LF, Reitsma JB, Bloemers FW, Goslings JC, et al. Missed injuries during the initial assessment in a cohort of 1124 level-1 trauma patients. Injury 2012;43:1517-21. [CrossRef]

3. Buduhan G, McRitchie DI. Missed injuries in patients with multiple trauma. J Trauma 2000;49:600-5. [CrossRef]

4. Brooks A, Holroyd B, Riley B. Missed injury in major trauma patients. Injury 2004;35:407-10. [CrossRef]

5. Janjua KJ, Sugrue M, Deane SA. Prospective evaluation of early missed injuries and the role of tertiary trauma survey. J Trauma 1998;44:1000-6.

6. Lee JC, Hennessy AD, Khafagi FA. Bone scans. Aust Fam Physician 2012;41:689-92.

7. Ball CG. Damage control surgery. Curr Opin Crit Care 2015;21:538-43.

8. Ferree S, Houwert RM, van Laarhoven JJ, Smeeing DP, Leenen LP, Hietbrink F. Tertiary survey in polytrauma patients should be an ongoing process. Injury 2016;47:792-6. [CrossRef]

9. Aaland MO, Smith K. Delayed diagnosis in a rural trauma center. Surgery 1996;120:774-8. [CrossRef]

10. Mallee WH, Wang J, Poolman RW, Kloen P, Maas M, de Vet HC, et al. Computed tomography versus magnetic resonance imaging versus bone scintigraphy for clinically suspected scaphoid fractures in patients with negative plain radiographs. Cochrane Database Syst Rev 2015:Cd010023. [CrossRef]

11. Byrne JP, Nathens AB, Gomez D, Pincus D, Jenkinson RJ. Timing of femoral shaft fracture fixation following major trauma: A retrospective cohort study of United States trauma centers. PLoS Med 2017;14:e1002336. [CrossRef]

12. Nahm NJ, Vallier HA. Timing of definitive treatment of femoral shaft fractures in patients with multiple injuries: a systematic review of randomized and nonrandomized trials. J Trauma Acute Care Surg 2012;73:1046-63. [CrossRef]

13. Yu SY, Wang W, Liu S, Ruan HJ, Liu JJ, Li XJ, et al. Arthrolysis and delayed internal fixation combined with hinged external fixation for elbow stiffness associated with malunion or nonunion of capitellum fracture. J Shoulder Elbow Surg 2015;24:941-6. [CrossRef]

14. Jackson LC, Pacchiana PD. Common complications of fracture repair. Clin Tech Small Anim Pract 2004;19:168-79. [CrossRef]

15. Lin JS, Piper MA, Perdue LA, Rutter CM, Webber EM, O'Connor E, et al. Screening for Colorectal Cancer: Updated Evidence Report and Systematic Review for the US Preventive Services Task Force. Jama 2016;315:2576-94. [CrossRef]

16. Health Quality Ontario. Ultrasound as an adjunct to mammography for breast cancer screening: a health technology assessment. Ont Health Technol Assess Ser 2016;16:1-71.

17. Eurin M, Haddad N, Zappa M, Lenoir T, Dauzac C, Vilgrain V, et al. Incidence and predictors of missed injuries in trauma patients in the initial hot report of whole-body CT scan. Injury 2012;43:73-7. [CrossRef]

18. Kritsaneepaiboon S, Jutiyon A, Krisanachinda A. Cumulative radiation exposure and estimated lifetime cancer risk in multiple-injury adult patients undergoing repeated or multiple CTs. Eur J Trauma Emerg Surg 2018;44:19-27. [CrossRef]

19. Shah KH, Slovis BH, Runde D, Godbout B, Newman DH, Lee J. Radiation exposure among patients with the highest $\mathrm{CT}$ scan utilization in the emergency department. Emerg Radiol 2013;20:485-91. [CrossRef]

20. Yun BJ, Myriam Hunink MG, Prabhakar AM, Heng M, Liu SW, Qudsi $\mathrm{R}$, et al. Diagnostic Imaging Strategies for Occult Hip Fractures: A Decision and Cost-Effectiveness Analysis. Acad Emerg Med 2016;23:11619. [CrossRef] 
ORİJINAL ÇALIŞMA - ÖZET

\section{Majör travma hastalarında atlanmış yaralanmanın saptanmasında kemik taramalarının geçerliliği}

\section{Dr. Maru Kim, Dr. Tae Hwa Hong, Dr. Hang Joo Cho}

Travma Cerrahisi Bölümü, Uijeongbu St. Mary’s Hastanesi, Kore Katolik Üniversitesi, Cheonbo-ro Uijeongbu-si-Güney Kore

AMAÇ: Majör travma hastalarında yaralanmaları atlamak kolaydır. Yazarlar, kemik taramalarının atlanmış yaralanmaların sayısını azaltacağı varsayımında bulunmaktadır. Ancak majör travma hastalarında kemik taramalarına ait yeterli kanıt yoktur. Bu çalışmanın amacı kemik taramalarının başlıca sonuçlarını tanımlamaktır.

GEREÇ VE YÖNTEM: Ocak 2013 ila Aralık 2013 arasında majör travma hastalarının tıbbi kayıtları gözden geçirildi ve kemik taramaları yapılan hastaların kayıtları incelendi. Daha önce değerlendirilmemiş yoğun tutulum gösteren sıcak noktalar direkt radyografiyle kontrol edildi. Daha önceki değerlendirmelerden farklı olarak kemik taramalarında yoğun tutulum gösteren lezyonlar bilgisayarlı tomografi taramalarıyla kontrol edildi. Kemik taramalarının sonuçları direkt radyografı ve bilgisayarlı tomografi taramalarının sonuçlarıyla birlikte analiz edildi Duyarılık, özgüllük, pozitif ve negatif öngördürücü değerler hesaplandı.

BULGULAR: Bu dönem içinde II 5 majör travma hastası kemik taramalarından geçirildi. Kemik taramalarının duyarlıık ve öngördürücü değerleri yüksek düzeylerdeydi (sırasıyla, \%98.48-\%86.54 ve \%96.30-\%82.93). Kemik taramaları atlanmış I6 kırık olgusuna tanı konuldu.

TARTIŞMA: Kemik taramaları yüksek bir duyarlılık ve negatif öngödücü değere sahiptir. Daha fazla sayıda geniş çaplı çalışma majör travma çalışmalarında kemik taramalarının majör travma hastalarında kullanımına daha fazla geçerlilik kazandırabilir.

Anahtar sözcükler: Atlanmış yaralanma; kemik taraması; travma; üçüncü araştırma.

Ulus Travma Acil Cerrahi Derg 2019;25(2): I83-I87 doi: 10.5505/tjtes.2018.55068 